\title{
Literature Review on Corporate Governance Structure and Performance in Non-Financial Firms in Bangladesh
}

\author{
Munshi Samaduzzaman (Corresponding author) \\ Accounting Lecturer, KAPLAN Business School, Sydney, Australia \\ E-mail: samaduzzaman@gmail.com \\ Fazluz Zaman \\ Business Trainer and Curriculum Writer \\ UOW College, University of Wollongong, Australia \\ E-mail: fazluzzaman@gmail.com \\ Zahurul Quazi \\ Coordinator, Vocational Education and Training \\ UOW College, University of Wollongong, Australia \\ E-mail: zahurulquazi@yahoo.com.au
}

Received: November 4, 2014 Accepted: Jan. 3, 2015 Published: June 1, 2015

doi:10.5296/ajfa.v7i1.6556 URL: http://dx.doi.org/10.5296/ajfa.v7i1.6556

\begin{abstract}
The need for the mechanism of corporate governance arises due to conflicts of interest between different stakeholders. Different stakeholders have different views and goals, as well as incomplete knowledge of each other's preferences. The whole world has seen the corporate scandals of big companies such as Enron, Tyco, WorldCom, Satyam Computer Services, etc. These collapses have brought into question the effectiveness of the corporate governance mechanism applied by organizations as part of regulating their affairs and books of accounts. This article discusses in detail the meaning and definition of corporate governance, examines corporate governance practices in Bangladesh, investigates Bangladesh's Corporate Governance Guidelines 2012 and performs a critical literature review on corporate governance structure and performance inside Non-Financial firms in Bangladesh.
\end{abstract}

Keywords: Audit Committee, Board of Directors, Corporate Governance, Directors, Executives, Stakeholders, Securities and Exchange Commission 


\section{Introduction}

According to Hess (1996), corporate governance (CG) is the process of administration and control of the firm's human resources and capital in the firm's owner's interest. Sternberg (1998) defines corporate governance as a way to ensure that corporate agents, assets and actions are directed towards reaching the objectives of the corporation which is expanded by its shareholders. The Centre of European Policy Studies (CEPS, 1995) indicates, in describing corporate governance, that it acts as a whole system of processes, rights and controls that is expanded externally and internally over the entity of business management with the aim of protecting stakeholders' interests. Shleifer and Vishny (1997) refer to corporate governance as being a way in which the corporation's financial suppliers ensure that they will receive an investment return.

According to O'Donovan (2003), corporate governance is an internal system that includes processes, policies and people that serve the requirements of shareholders as well as other stakeholders by controlling and directing activities by the firm's management with good business objectivity, savvy and integrity. Sound corporate governance is related to external marketplace legislation and to a commitment to adding a healthy board culture that protects processes and policies. In other words, corporate governance is defined as the moral, ethical and legal corporation values that safeguard stakeholders' interests.

Classens (2003) argues that corporate governance definitions, although widely varied, can be categorized into two sets. The first set of definitions deals with a behavioural pattern set that comprises the corporation's actual behaviour, namely, its efficiency, financial structure, performance, growth and treatment of shareholders and other stakeholders. The second set of definitions deals with the normative framework. Corporate governance is based on rules under which companies operate including judicial systems, financial markets, legal systems and labour or factor markets. According to Blair (1995), corporate governance is the whole set of cultural, institutional and legal arrangements that identify what public-trading corporations can perform, who controls corporations, how the control is being exercised and how the activities, risks and returns are allocated.

Saidi (2004) points out that corporate governance is the system by which firms can be controlled and directed, and adds that the responsibility for corporate governance lies with the shareholders, board of directors (BOD) and the management. These groups also act as principal players in the corporate governance process. Other than the shareholders, management and board of directors, other stakeholders included in the process are suppliers, regulators, employees, creditors, the environment, customers and the community at large. Likewise, according to Gillibrand (2004), the corporate governance structure deals with procedures and rules that are used for making decisions on corporate affairs. Corporate governance provides the structure through which the objectives of the firm can be framed and by which the performance of these objectives can be monitored and achieved. Corporate governance is the system of operating, structuring and controlling a firm with a view to reaching long-term strategic goals that fulfill the expectations of creditors, shareholders, suppliers and customers, while operating in compliance with regulatory and legal 
requirements. Thus, corporate governance is defined as the set of rules and regulations that are framed to protect corporate values and shareholders' interests.

\section{Corporate Governance in Bangladesh}

According to Jahangir (2008), corporate governance practices among Bangladeshi companies are just emerging. The establishment of a corporate governance framework relies on the principles of justice, fairness and open access. The model of control-based governance which is applied within listed companies in Bangladesh is damaging to investors' confidence and also hurts stock market development. In Bangladesh, many listed firms, with the exception of multinational corporations and a few large firms, are managed, owned and controlled by family members and their peers. Policy decisions usually made by board members are made by company owners who dispose of the firm's executive functions, leaving no scope for the isolation of board independence and ownership.

Ahmed and Yusuf (2005) point out that the current corporate governance system in Bangladesh does not facilitate sufficient economic, institutional and legal motivation for stakeholders to enforce and encourage corporate governance practices. All corporate governance systems revolve around four principles: responsibility, fairness, transparency and accountability. The specific challenges associated with these principles rely on the corporate sector's ownership and structure. In Bangladesh, family members manage the structure of the corporation. This practice hinders the levels of accountability, fairness and transparency. The provision and enforcement of processes and bankruptcy laws are inadequate. No country can have good corporate governance standards if it has poor processes and bankruptcy laws. Securitization processes and inefficient foreclosures have become major issues in Bangladesh. Most Bangladeshi firms have a pessimistic approach in order to attract foreign investment. The outcome is a lack of drive from the international investor community for better corporate governance and, thus, investor penetration levels of Bangladeshi firms in foreign investment stock exchanges will be very low (Hossain, 2005).

For effective corporate governance in Bangladesh and a family-based management style, Ahmed, Alam, Jafarand Zaman (2008) recommend that the following significant measures must be undertaken. Members of the board have to be elected from all shareholder groups in the proportion of their shareholding. For the chairmanship, the maximum term must be mentioned and rotated among the directors. The board must appoint the top five managers encompassing the Chief Executive Officer (CEO) who must remain on the board. Auditors have an essential role in ensuring compliance with Bangladesh's Corporate Governance Guidelines. All investors rely on the integrity of the auditor who must provide investors with some assurance that the investments have credibility. Accounting has changed from cash accounting to accrual accounting: accounting estimates, in part, are also included, playing a critical role in estimating firms' profits, especially for more complex businesses in economies related to knowledge. Organizations must frame a code of conduct for their executives and directors that is based on responsibility and ethical decision making. They also have to clarify and publicly represent the responsibilities and roles of the management and board. Firms must create purposeful and stronger boards, improve the timing, accuracy and scope of 
financial reporting and concentrate on the interests and rights of minority shareholders. Tough accounting standards, proper security and corporate laws, efficient judicial systems and effective regulators together can ensure the foundations of good corporate governance.

\section{Bangladesh Corporate Governance Guidelines 2012}

On 3 July 2012, the Bangladesh Securities and Exchange Commission (BSEC) released the revised Corporate Governance Guidelines for Bangladesh. In these guidelines, under board effectiveness, the following revisions were made: separation between the roles of CEO and chairman is required; at least one-fifth of the independent directors must be present at meetings; and the independent director requirements must meet extra criteria including specific qualifications criteria. In addition, the revisions stated that: the firm must not enter into any illegal or fraudulent transactions or any transactions that violate the firm's code of conduct; independent directors must be nominated by the board of directors and shareholders must approve the nomination at the annual general meeting; the post of independent director should not be vacant for more than 90 days; the code of conduct applies to all members of the board as does annual compliance; and the normal tenure of the independent director is three years which can be extended for only one term. In relation to audit committee (AC) affairs, the following guidelines were revised: the chairman of the audit committee shall be an independent director; ten (10) specific roles of the audit committee must be identified with professional qualifications needed for all members; one independent director is required at meetings to satisfy the audit committee's quorum; and the audit committee's chairman must be present at the annual general meeting. In addition, the revised guidelines state that: the company secretary may also act as the audit committee secretary and that the audit committee must report any material identification to the BSEC after the expiry of every six-month period from the date of its first report to the board of directors or after reporting to the board three times when it must be reported to the BSEC earlier. In terms of auditor independence, the revised guidelines state that neither any partner nor any employee of the external auditing firm can hold any shares in the client company during the audit assignment term.

In relation to governance of a subsidiary firm, the revised guidelines are as follows: the subsidiary firm's board composition must be the same as the holding firm; the holding firm may appoint one of its independent directors to act as a subsidiary firm director; and the board meeting minutes of the subsidiary firm can be presented to the holding firm's board meeting for review. In addition, the revised guidelines are that: the holding firm's board meeting minutes may state that the board has already reviewed the subsidiary firm's affairs and that the audit committee of the holding firm may review the subsidiary firm's financial statements encompassing any investment made by the subsidiary firm. In relation to additional statements by the board of directors, the revised guidelines are as follows: the outlook and possible future developments in the respective industry have to be specified; product-wise or segment-wise performance has to be specified; and various risks faced by the organization and related issues must be mentioned. In addition, discussion in the additional statements is to include: the cost of products sold; net profit margin and gross profit margin of the firm; the continuity of any extraordinary loss or gain; remuneration to board members; a statement of all transactions related to any party encompassing the basis of party 
transactions; and the application of funds increased from rights issues, public issues or through other instruments (Biswas, 2012).

\section{Critical Literature Review on Corporate Governance Structure and Performance in Non-Financial Firms in Bangladesh}

Rouf (2010) carried out an investigation to determine the characteristics of linkages between corporate governance attributes and their influence on voluntary disclosure as presented in the annual reports of listed firms in Bangladesh. For this analysis, data were collected from the sample of 120 Non-Financial firms listed on the Dhaka Stock Exchange (DSE) in 2008. The corporate governance factors that were examined included: board size; independent non-executive directors as members of the board; structure of the board leadership; board audit committee; percentage of equity owned by insiders in relation to the firm's overall equity; and the firm's profitability. Ordinary least squares (OLS) regression was used in this analysis to determine the relationship between voluntary disclosure and explanatory variables. It was also used to assess the impact of each and every variable presented in the disclosure data with this linked to the index of aggregate disclosure and used to test the proposed hypotheses. The un-weighted relative disclosure index measured voluntary disclosure in Rouf's (2010) study with the study also using Pearson's correlation analysis. In the findings, a positive relationship was observed between board size and voluntary disclosure; between the board having an audit committee and voluntary disclosure; and between the structure of board leadership and voluntary disclosure. Negative associations were observed between voluntary disclosure and the proportion of independent directors, net profitability and the ownership structure. Thus, in the study's conclusions, a positive relationship was found between board size, board audit committee, board leadership structure and voluntary disclosure. Voluntary disclosure had a negative relationship with the ownership structure and net profitability.

Siddiqui (2012) conducted a study to analyse the determinants of the capital structure of Non-Financial institutions in Bangladesh. The source of the data was the Bangladesh Bank database which collects information regarding Bangladesh's Non-Financial institutions with 24 of the listed Non-Financial institutions selected for this study. Feasible generalized least squares (FGLS) regression was used to gauge the explanatory variables' effects on the dependent variables. The FGLS regression technique was used to estimate the variance-covariance matrix. As cross-sectional time series panel data were used for this analysis, the data may have had the problem of heteroscedasticity. However, FGLS regression automatically corrects the problem of heteroscedasticity if it exists among the variables. Eight factors were identified, namely: liquidity ratio; growth rate; debt service coverage; tangibility ratio; operating leverage; profitability ratio; firm age; and firm size, and their debt ratio relationships were studied. It was observed that leverage ratios of all these factors increased with a rise in firm size and growth rate. Operating leverage, debt service coverage and age were also observed as being negatively associated with three debt ratios, namely, the short-term ratio, total-term ratio and long-term ratio. In terms of ratios for liquidity, profitability and tangibility, mixed results were found. Firm age was not significant for all three cases. Long-term debt ratio was maximized with an increase in tangibility and 
liquidity ratios, while total-term and short-term debt ratios declined with an increase in tangibility and liquidity ratios.

Rashid, Lodh, De Zoysa and Rudkin (2010) carried out a study to determine the influence of board composition, with regard to the representation of external independent directors, on companies' economic performance in Bangladesh. Data were collected from 90 Non-Financial firms listed on the Dhaka Stock Exchange (DSE) during the period from 2005 to 2009. A regression model was used to determine the relationship between board composition and firm performance. No significant relationship was found to exist between board composition in terms of representation from external independent directors and firm performance. This result implied that the external independent director cannot add potential economic value to the Bangladesh firm. The size of the board was observed to have a negative and significant influence on firm performance under accounting based on the performance measures. This implied that information asymmetries exist between external independent directors and other directors. In the findings, it was also noted that external independent directors from Bangladesh companies were unable to ensure that checks and balances were in place in the accounts and in the activities of management. Board size was found to have a negative influence on firm performance under the return on assets (ROA) measure. It was concluded that, while introducing independent directors will have advantages for greater transparency, in the emerging economy such as in Bangladesh, due to the presence of cultural and institutional difference, it will not add potential economic value to the company. From the policy point of view, the findings of Rashid et al.'s (2010) research will be helpful in providing extra insight to regulators in harmonizing the practices of corporate governance in Bangladesh with international corporate governance best practices.

Sufian and Zahan (2013) examined the relationship between ownership structure and corporate social responsibility disclosure(CSRD) in Bangladesh. Data were collected from 254 firms listed on the Dhaka Stock Exchange (DSE). Of these firms, the categories of financial institution, real estate, bank, insurance, travel and leisure, and mutual fund were excluded from the sample data. Firms usually disclose corporate social responsibility (CSR) information in many ways, namely, published articles or advertisements which explain the firm's activities; annual reports; corporate websites; leaflets or booklets; interim and quarterly reports addressing the firm's social activities; special announcements; employee reports; environmental reports; and press reports. Data were collected from these sources and analysed using OLS regression to determine the relationship between corporate structure variables and corporate social responsibility disclosure (CSRD). To assess the degree of disclosure made by listed firms in Bangladesh, a sophisticated statistical measure, namely, multivariate regression was used to analyse the collected data with the help of Statistical Package for the Social Sciences (SPSS) software. The coefficient of board size was observed to be negatively associated with corporate social responsibility disclosure (CSRD). The coefficients of the number of external shareholders, ownership concentration and foreign ownership were positively correlated with corporate social responsibility disclosure (CSRD). The relationship between concentrated ownership and CSRD was also found to be positive. Companies with a higher concentration of ownership disclosed less CSR information than 
companies with a lower ownership concentration. It was concluded that no significant relationship existed between CSRD and other ownership structure variables such as foreign ownership, number of shareholders and size of the board.

Rouf (2012) later examined the relationship between profitability, that is, financial performance and the level of corporate governance disclosure (CGD)by listed Non-Financial firms in Bangladesh. Data were collected from the 2007 annual reports of the 94 listed firms selected for this study. The OLS method and multiple regression analysis were used to estimate corporate governance disclosure. Independent variables such as board audit committee, profitability, size of the firm and ownership structure were examined. Corporate governance disclosure was measured using 40 items of information performance and financial performance, that is, profitability which was measured by return on assets (ROA).The unweighted approach, which is mainly used for measuring corporate governance disclosure, was used as this approach is most appropriate when no significance is provided to any specific user groups. After the establishment of the disclosure index, a scoring sheet was developed to obtain the extent of the disclosures of corporate governance. The firm's positive profitability was identified as being correlated to CGD which was positively associated with the return on equity and the board audit committee. Corporate governance disclosure (CGD) was also observed as being negatively associated with the ownership structure. Despite the positive correlation between CGD and total sales and total assets, they did not have a significant relationship. Thus, it was concluded that the disclosure level of corporate governance was positively associated with the size of the firm. Corporate governance disclosure (CGD) was also positively and significantly associated with profitability, that is, financial performance. This research by Rouf (2012) provided empirical evidence to regulators and policy makers in South Asia.

\section{Conclusion}

Corporate governance is an internal system which includes policies, people and processes that serve the needs of shareholders and other stakeholders by controlling and directing the activities of management with good business savvy, objectivity and integrity. Corporate governance is referred to as the set of policies, regulations and rules which is framed to safeguard the values of corporate shareholders' interests. It is important in ensuring that responsibility and accountability must be incorporated into each and every part of the company or organization. Present corporate governance practice in Bangladesh does not provide sufficient legal, economic and institutional motivation for stakeholders to boost and enforce the new corporate governance practices. All current systems of corporate governance practice are centred on the four principles of transparency, fairness, responsibility and accountability. The specific challenges related to these principles depend on the ownership structure in the respective corporate sector. In Bangladesh, the corporate governance structure is mostly managed and owned by family members with this practice hindering the level of fairness, transparency and accountability. Bankruptcy laws and other such processes are not appropriate in terms of provision and enforcement. 


\section{References}

Ahmed, H. L., Alam, M. J., Jafar, S. A. \& Zaman, S. S. (2008). A Conceptual Review on Corporate Governance and Its Effect on Firm's Performance: Bangladesh Perspective, AIUB Business and Economics Working Paper Series.

Ahmed, M. U. \& Yusuf, M. A. (2005). Corporate Governance: Bangladesh Perspective. Cost and Management, 33(6),18-26.

Bangladesh Securities and Exchange Commission (BSEC).(2012).Corporate Governance Guidelines. Retrieved 15 September 2014 from:

http://www.secbd.org/Notification\%20on\%20CG-07.8.12-Amended.pdf

Biswas, K. (2012). Corporate Governance Guidelines in Bangladesh: Some Observations. Cost and Management, 5-9.

Blair, M.M. (1995).Ownership and Control: Rethinking Corporate Governance for the $21^{\text {st }}$ Century. Brookings Institute, Washington, DC.

Centre of European Policy Studies (CEPS).(1995).Cited in Shleifer, A and Vishny, R. (1997), A Survey of Corporate Governance. Journal of Finance, 52, 737-783. http://dx.doi.org/10.1111/j.1540-6261.1997.tb04820.x

Classens, S. (2003). Corporate Governance and Development, Focus 1, Global Corporate Governance Forum, World Bank, Washington.

Gillibrand, M. (2004). Corporate management essential for industrialization. The Bangladesh Observer, Bangladesh.

Hess, G. (1996). Zum Stand der Diskussion in den Vereinigten Staaten. In Feddersen, D., Hommelhoff, P. and Schneider, U. H. (eds.). Corporate Governance. Otto Schmidt-Verlag, Köln.

Hossain, M. (2005). Why Shareholders' Activism is Still an Illusion in Bangladesh. The Financial Express, Dhaka.

Jahangir, A. (2008). Financial Disclosure in Developing Countries with Special Reference to Bangladesh. Doctoral Dissertation, University of Ghent, Belgium.

O’Donovan. G. (2003). Change Management - A Board Culture of Corporate Governance. Mondaq Business Briefing.

Rashid, A. Lodh, S., De Zoysa, A. \& Rudkin, K. (2010). Board Composition and Firm Performance: Evidence from Bangladesh. Australasian Accounting Business and Finance Journal, Research Online, 4(1), 76-95.

Rouf, A. (2010). Corporate Characteristics, Governance Attributes and the Extent of Voluntary Disclosure in Bangladesh. Asian Journal of Management Research, 166-183. 


\section{Macrothink}

Asian Journal of Finance \& Accounting ISSN 1946-052X 2015, Vol. 7, No. 1

Rouf, A. (2012). The Financial Performance and Corporate Governance Disclosure: A Study in the Annual Reports of Listed Companies of Bangladesh. Pakistan Journal of Commerce and Social Sciences, 6(1), 1-11.

Saidi, N. (2004).Corporate Governance and Business Ethics. Launching Ceremony of RDCL's [Lebanese Businessmen Association] 'Code of Business Ethics'. Beirut, Lebanon.

Shleifer, A. \&Vishny, R. (1997). A Survey of Corporate Governance. Journal of Finance, 52, 737-783. http://dx.doi.org/10.1111/j.1540-6261.1997.tb04820.x

Siddiqui, S. (2012). Capital Structure Determinants of Non-Financial Institutions in Bangladesh. World Review of Business Research, 2, 60-78.

Sternberg, E. (1998).Corporate Governance: Accountability in the Marketplace, Institute of Economic Affairs, London.

Sufian, A. \& Zahan, M. (2013), Ownership Structure and Corporate Social Responsibility Disclosure in Bangladesh. International Journal of Economics and Financial Issues, 3(4), 901-909. 